Gelanggang Olahraga: Jurnal Pendidikan Jasmani dan Olahraga

Volume 1, Nomor 2, Januari-Juni 2018

e-ISSN : 2597-6567

p-ISSN : 2614-607X

DOI : https://doi.org/10.31539/jpjo.v1i2.169

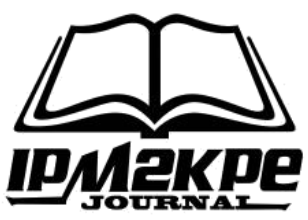

\title{
MENINGKATKAN HASIL BELAJAR SISWA DENGAN METODE DEMONSTRASI PADA PERMAINAN BOLA BASKET PADA SEKOLAH DASAR
}

\author{
Hafridarli \\ Sekolah Dasar Negeri 22 Koto Baru \\ hafridarli@gmail.com
}

\begin{abstract}
ABSTRAK
Tujuan dari penelitian ini adalah untuk meningkatkan hasil belajar siswa pada permainan bola basket dengan metode demonstrasi bagi siswa kelas V SDN 22 Koto Baru. Metode penelitian yang peneliti gunakan untuk penelitian tindakan kelas(PTK) yaitu penelitian tindakan yang dilakukan di kelas untuk meningkatkan hasil belajar siswa. Penelitian ini dilaksanakan dalam 2 siklus. Setiap siklus terdiri atas langkah perencanaan, pelaksanaan, observasi, dan refleksi. Penelitian ini dilaksanakan di SDN 22 Koto Baru. Penelitian ini dilakukan pada bulan agustus sanpai dengan november 2017 di kelas V C SDN 22 Koto Baru, hasil penelitian menunjukkan bahwa pembelajaran dengan metode demonstrasi, tidak hanya dapat meningkatkan hasil belajar siswa pada aspek pengetahuan, akan tetapi juga dapat meningktkan keterampilan siswa karena siswa dalam pembelajaran diminta secara langsung mendemonstrasikan gerakan-gerakan dalam permainan bola basket. Dengan demikian, disarankan bahwa guru diharapkan menggunkan metode demonstrasi dalam pembelajaran dan siswa sebaiknya mendengarkan setiap informasi yang disampaikan guru, agar pembelajaran yang akan dilaksanakan berjalan dengan lancar .
\end{abstract}

Kata Kunci: Hasil Belajar, Metode Demonstrasi, Permainan Bola Basket

\section{ABSTRACT}

The purpose of this study is to improve student learning outcomes on basketball games with demonstration methods for students of class V SDN 22 Koto Baru. Research methods that researchers use for classroom action research (PTK) is action research conducted in the classroom to improve student learning outcomes. This study was conducted in 2 cycles. Each cycle consists of planning, implementation, observation, and reflection. This research was conducted at SDN 22 Koto Baru. This research was conducted in August with the november 2017 in VC SDN 22 Koto Baru class, the result of the research shows that learning by demonstration method can not only improve the students 'learning outcomes on the knowledge aspect but also can improve the students' skills because the students in the learning are asked directly demonstrating the movements in basketball games. Thus, it is suggested that teachers are expected to use demonstration methods in learning and students should listen to any information submitted by the teacher, so that the learning will run smoothly.

Keywords: Learning Outcomes, Demonstration Methods, Basketball Games 


\section{PENDAHULUAN}

Pendidikan merupakan salah satu faktor yang penting dalam kehidupan manusia. Sebagai suatu sistem yang kompleks, pendidikan harus dilakukan dengan perencanaan, pengelolaan, serta pengevaluasian yang baik, sehingga menghasilkan manusia yang berkualitas, baik dalam hal pengetahuan, sikap maupun keterampilan. Keberhasilan suatu pendidikan dalam menciptakan manusia yang berkualitas, dapat dipengaruhi beberapa faktor, salah satunya yaitu pertumbuhan dan perkembangan kualitas fisik manusia. Manusia yang berkualitas secara fisik dan psikis akan melancarkan jalanya sistem pendidikan di indonesia.

Pendidikan jasmani, olahraga dan kesehatan merupakan media untuk mendorong pertumbuhan fisik, perkembangan psikis, keterampilan motorik, pengetahuan dan penalaran, penghayatan nilai-nilai, serta pembiasaan pola hidup sehat yang bermuara untuk merangsang pertumbuhan dan perkembangan kualitas fisik dan psikis yang seimbang. Hal ini sesuai dengan tujuan Pendidikan Jasmani Olahraga dan Kesehatan secara keseluruhan yaitu untuk mengembangkan aspek kebugaran jasmani, keterampilan gerak, keterampilan berfikir kritis, keterampilan sosial, penalaran, stabilitas emosional, tindakan moral, aspek pola hidup sehat, dan pengenalan lingkungan bersih melalui aktifitas jasmani, Olahraga dan kesehatan terpilih (Permendiknas Nomor 22 Tahun 2006). Jadi, dengan melaksanakan proses pembelajaran jasmani Olahraga dan Kesehatan dengan baik, maka diharapkan siswa memiliki perkembangan fisik dan psikis yang baik, sehingga memudahkan tercapainya tujuan pendidikan di indonesia.

Salah satu materi pendidikan jasmani, olahraga dan kesehatan adalah materi permainan bola basket. materi permainan bola basket termasuk kedalam salah satu materi pelajaran dikelas V. Di SDN 22 Koto Baru guru - guru telah menerapkan kurikulum 2013 yang dalam penerapkannya siswa di wajibkan belajar dengana cara mengamati dan memahami baik secara individu, maupun mendiskusikannya secara berkelompok. Dengan kata lain, siswa menemukan pengetahuannya sendiri melalui bimbingan guru, sehingga pengetahuan yang diperoleh lebih bermakna. Namun, realita yang terjadi adalah sebaliknya, yaitu hasil belajar siswa kurang memuaskan.

Proses pembelajaran materi permainan bola basket dikelas V C ini, memerlukan metode yang dalam implementasinya masih membutuhkan keaktifan guru, akan tetapi tidak menyempingkan tuntuan kurikulum 2013 yaitu, menggunakan pendekatan scientific dalam pembelajaran, sehingga siswa tetap menemukan sendiri pengetahuannya. Dengan kata lain, metode yang diperlukan tidak hanya membantu siswa memahami materi, akan tetapi juga memperoleh berbagai keterampilan dan sikap yang dapat diterapkan dalam kehidupan seharihari.

Salah satu metode yang dapat digunakan guru dalam proses pembelajaran materi bola basket ini adalah menggunakan metode demontrasi. Metode demontrasi merupakan metode yang dilakukan dengan cara memperagakan cara kerja, alat, urutan kegiatan baik secara langsung atau dibantu media media pembelajaranyang sesuai dengan materi pembelajaran. Metode demonstrasi bertujuan untuk memperjelas konsep dan proses terjadinya sesuatu, sehinggga siswa dapat secara langsung melihat proses tersebut. Metode ini memiliki beberapa kelebihan diantaranya memperjelas dan mengkonktretkan materi pembelajaran, mempermudah pemahaman siswa, meningkatkan ketertarikan 
siswa akan materi, memusatkan perhatian siswa, merangsang siswa untuk aktif mengamati, meningkatkan daya serap siswa terhadap materi berdasarkan pengalaman kesan yang didemokan, meningkatkan aktivitas belajar siswa karena terlibat dalam melakukan demonstrasi, menghemat waktu dan membangkitkan minat dan aktifitas belajar siswa (Jamil, 2013), penelitian ini bertujuan untuk meningkatkan hasil belajar siswa mengenai permainan bola basket dengan metode demonstrasi di kelas V C SDN 22 Koto Baru.Berhasil atau tidaknya proses belajar dipengaruhi oleh banyak faktor. Salah satunnya yaitu metode yang digunakan guru dalam pembelajaran. Menurut Jamil (2013) Guru perlu mengadakan variasi gaya mengajar agar suasana pembelajaran tidak membosankan. Variasi gaya mengajar ini erat kaitannya dengan hasil belajar, karena variasi mengajarakan menjadikan proses pembelajaran lebih dinamis, dan mengintenfikasikan komunikasi anatara guru dan siswa. Salah satu variasi gaya mengajar adalah variasi metode mengajar. Bola basket adalah permainan yang dimainkan oleh dua regu, yang masing-masing regu terdiri dari lima orang pemain. Tujuan permainan ini adalah membuat nilai sebanyak-banyaknya dengan memasukan bola kekeranjang lawan dan mencegah pemain lawan membuat nilai atau sebaliknya.

Penerapan metode demonstrasi dalam pembelajaran, dapat memperjelas konsep materi, mempermudah pemahaman siswa, meningkatkan ketertarikan siswa akan materi, memusatkan perhatian siswa, merangsang siswa untuk aktif mengamati,meningkatkan daya serap siswa terhadap materi berdasarkan pengalaman dan kesan yang didemokan serta meningkatkan aktivitas belajar siswa karena terlibat dalam melakukan demonstrasi. Dengan metode demonstrasi dalam pembelajaran, akan meningkatkan hasil belajar siswa terutama pada aspek pengetahuan, keterampilan dan sikap

\section{KAJIAN TEORI \\ Hasil Belajar}

Proses belajar yang telah terjadi dalam diri seseorang yang dapat disimpulkan dari hasilnya. Hasil belajar merupakan perubahan yng terjadi pada individu, yang terjadi pada individu, yang terjadi sebagai akibat dri kegiatan belajar yang telah dilakukan oleh individu tersebut (Syaiful, 2008). Pendapat senada juga dikemukakan oleh Jamil (2013) menyatkana bahwa hasil belajar dapat dibedakan dalam tiga aspek, yaitu :

1. Aspek kognitif, yaitu kemampuan yang berhubungan dengan berpikir, mengetahui dan memecahkan masalah . Kawasan kognitif berkenaan dengan proses mental yang berawal dari tingkat pengetahuan sampai ketingkat yang lebih tinggi, yaitu evaluasi

2. Aspek afektif, yaitu kemampuan yang berhubungan dengan sikap, minat, nilai dan apresiasi

3. Aspek psikomotor yaitu aspek yang mencakup tujuan yang berkaitan dengan keterampilan yang bersifat manual atau motorik. Tingkatan aspek psikomotorik ini dimulai dari persepsi, kesiapan melakukan suatu kegiatan, mekanisme, respons terbimbing, kemahiran, adaptasi, dan organisasi

Berdasarkan pendapat ahli di atas, dapat disimpulkan bahwa hasil belajar dari kegiatan belajar. Perubahan tersebut berupa perubahan pengetahuan, sikap dan keterampilan 


\section{Metode Demonstrasi}

Berhasil atau tidaknya proses belajar dipengaruhi oleh banyak faktor. Salah satunnya yaitu metode yang digunakan guru dalam pembelajaran. Menurut Jamil(2013) Guru perlu mengadakan variasi gaya mengajar agar suasana pembelajaran tidak membosankan. Lebih lanjut Jamil menjelaskan bahwa variasi gaya mengajar ini erat kaitannya dengan hasil belajar, karena variasi mengajar akan menjadikan proses pembelajaran lebih dinamis, dan mengintenfikasikan komunikasi anatara guru dan siswa. Salah satu variasi gaya mengajar adalah variasi metode mengajar.

Metode demonstrasi adalah cara penyajian pelajaran dengan memperagakan atau mempertunjukkan kepada peserta didik suatu proses, situasi atau benda tertentu yang sedang dipelajari baik dalam bentuk sebenarnya maupun dalam bentuk tiruan yang dipertunjukkan oleh guru atau sumber belajar lain yang ahli dalam topik bahasan (Ratna, 1989). Menurut Suryabrata (1983) metode demonstrasi adalah suatu cara penyampaian materi dengan memperagakan suatu proses atau kegiatan.

Berdasarkan pengertian di atas, dapat disimpulkan bahwa metode demonstrasi adalah adalah metode mengajar yang menggunakan peragaan untuk memperjelas suatu pengertian atau untuk memperlihatkan bagaimana melakukan sesuatu kepada anak didik atau cara guru dalam mengajar dengan memperagakan dan mempertunjukkan kepada siswa suatu proses, situasi, kejadian, urutan melakukan suatu kegiatan atau benda tertentu yang sedang dipelajari baik dalam bentuk yang sebenarnya maupun tiruan melalui penggunaan berbagai macam media yang relevan dengan pokok bahasan untuk memudahkan siswa agar kreatif dalam memahami materi.

\section{Permainan Bola Basket}

Bola basket adalah permainan yang dimainkan oleh dua regu, yang masing-masing regu terdiri dari lima orang pemain. Tujuan permainan ini adalah membuat nilai sebanyak-banyaknya dengan memasukan bola ke keranjang lawan dan mencegah pemain lawan membuat nilai atau sebaliknya. Dalam memainkan bola pemain dapat mendorong bola, memukul bola dengan telapak tangan terbuka, melemparkan menggelinding atau mengiring bola ke segala arah dalam lapangan permainan. Sodikun (1992) yang mengemukakan bahwa permainan bolabasket merupakan permainan yang gerakannya kompleks, yaitu gabungan dari jalan, lari, lompat dan unsur kekuatan, kecepatan, ketepatan, kelentukan, dan lain-lain. Untuk dapat melakukan gerakan-gerakan bolabasket dengan baik, diperlukan kemampuan dasar fisik yang memadai. Dengan kondisi fisik yang baik, akan memudahkan melakukan gerakan-gerakan yang lebih sulit (kompleks). Berdasarkan pada pengertian tersebut, dapat disimpulkan bahwa yang dimaksud dengan permainan bola basket adalah permainan yang gerakannya 24 kompleks, yaitu gabungan dari jalan, lari, lompat dan unsur kekuatan, kecepatan, ketepatan, kelentukan, dan lain-lain dengan bantuan bola dan keranjang sebagai sasaran.

Adapun perlengkapan dalam bermain bola basket adalah sepatu bola basket. Celana atlet, t-shirt longgar, kaos kaki putih dan dapat juga memakai soft pada untuk melindungi lutut dan siku serta kaca mata untuk melinduingi mata. 1. Bola basket Bola basket berbentuk bulat bundar (spherical) dan berwarna orange. Keliling bola basket untuk laki adalah maksimum $30 \mathrm{~cm}$ dan minimum 29,5 cm, 
sedangkan untuk wanita maksimum $29 \mathrm{~cm}$ dan minimum 28,5 cm. 2. Papan ring (back-board) Papan ring (back-board) bebentuk persegi panjang dengan permukaan datar, berukuran horisontal 1,80 m dan vertikal 1,05 $\mathrm{m}$. suatu kotak persegi panjang berukuran24 inci horisontal dan 18 inci vertikal diletakkan dibelakang ring dengan garis bawahnya sejajar dengan tiang tiap keranjang berdiameter $18 \mathrm{~cm}$ dengan sisis permukaan 2,90 m diatas lantai. 3 .

Dimensi lapangan dan tanda-tanda Lapangan pertandingan berbentuk persegi panjang dengan permukaan bebas hambatan dengan dimensi 16 X $28 \mathrm{~m}$. pada bagian-bagian tertentu dari lapangan diberinama khusus, dimana garis batas pada tiap sisi dan garis bagian akhir dari lapangan disebut sideline, endline dan centerline. Frountcourt dan suatu tim adalah separuh lapangan dari garis batas akhir 25 belakang dan sisi terdekat dari division atau garis tengah lapangan (nidcourline) termasuk ring basket kubu tim itu. Sedangkan backcourt mencakup setengah lapangan lainnya dimana terdapat ring basket tim lawan. Ada tiga lingkaran dilapangan, lingkaran lemparan bebas (free throw circle) pada bagian tiap lapangan dan lingkaran tengah. (center circle). Garis dari sisi belakang dari free circle dan tanda baseline adalah daerah yang disebut sebagai free throw lane dan key. Sedangkan tanda-tanda tambahan pada tiap sisi dari lane lines disebut block dan hash marks

\section{METODE PENELITIAN}

Penelitian Tindakan Kelas (PTK). Secara etimologis, ada tiga istilah yang berhubungan dengan PTK, yakni penelitian, tindakan, dan kelas (Wina Sanjaya, 2010). Pertama, penelitian adalah suatu proses pemecahan masalah yang dilakukan secara sistematis, empiris, dan terkontrol. Sistematis dapat diartikan sebagai proses yang runtut sesuai dengan aturan tertentu. Artinya, proses penelitian harus dilakukan secara bertahap mulai dari menyadari adanya masalah, sampai proses pemecahannya melalui teknik analisis tertentu untuk ditarik kesimpulan. Hal ini berarti, suatu kerja penelitian tidak dilakukan secara acak, akan tetapi dikerjakan melalui rangkaian proses yang ajek sesuai dengan kaidahkaidah berpikir ilmiah. Empiris mengandung arti bahwa kerja penelitian harus didasarkan pada data-data tertentu. Proses pengambilan kesimpulan tidak didasarkan pada khayalan imajinatif peneliti, akan tetapi harus didukung dan didasarkan oleh adanya temuan data dan fakta. Terkontrol artinya suatu kerja penelitian harus didasarkan pada proses kerja yang jelas, sehingga orang lain dapat membuktikan hasil temuan penelitian yang diperoleh.

Kedua, tindakan dapat diartikan sebagai perlakuan tertentu yang dilakukan oleh peneliti yakni guru. Tindakan diarahkan untuk memperbaiki kinerja yang dilakukan guru. Dengan demikian, dalam PTK bukan didorong hanya ingin tahu sesuatu, akan tetapi disemangati oleh adanya keinginan untuk memperbaiki kinerja untuk mencapai hasil belajar yang maksimal. Hal inilah yang menjadi ciri khas PTK yang tidak akan ditemukan di dalam jenis penelitian yang lain.

Ketiga, kelas menunjukkan pada tempat proses pembelajaran berlangsung. Berarti PTK dilakukan di dalam kelas yang tidak di-setting untuk kepentingan penelitian secara khusus, akan tetapi PTK berlangsung dalam keadaan situasi dan kondisi yang riil tanpa direkayasa. 


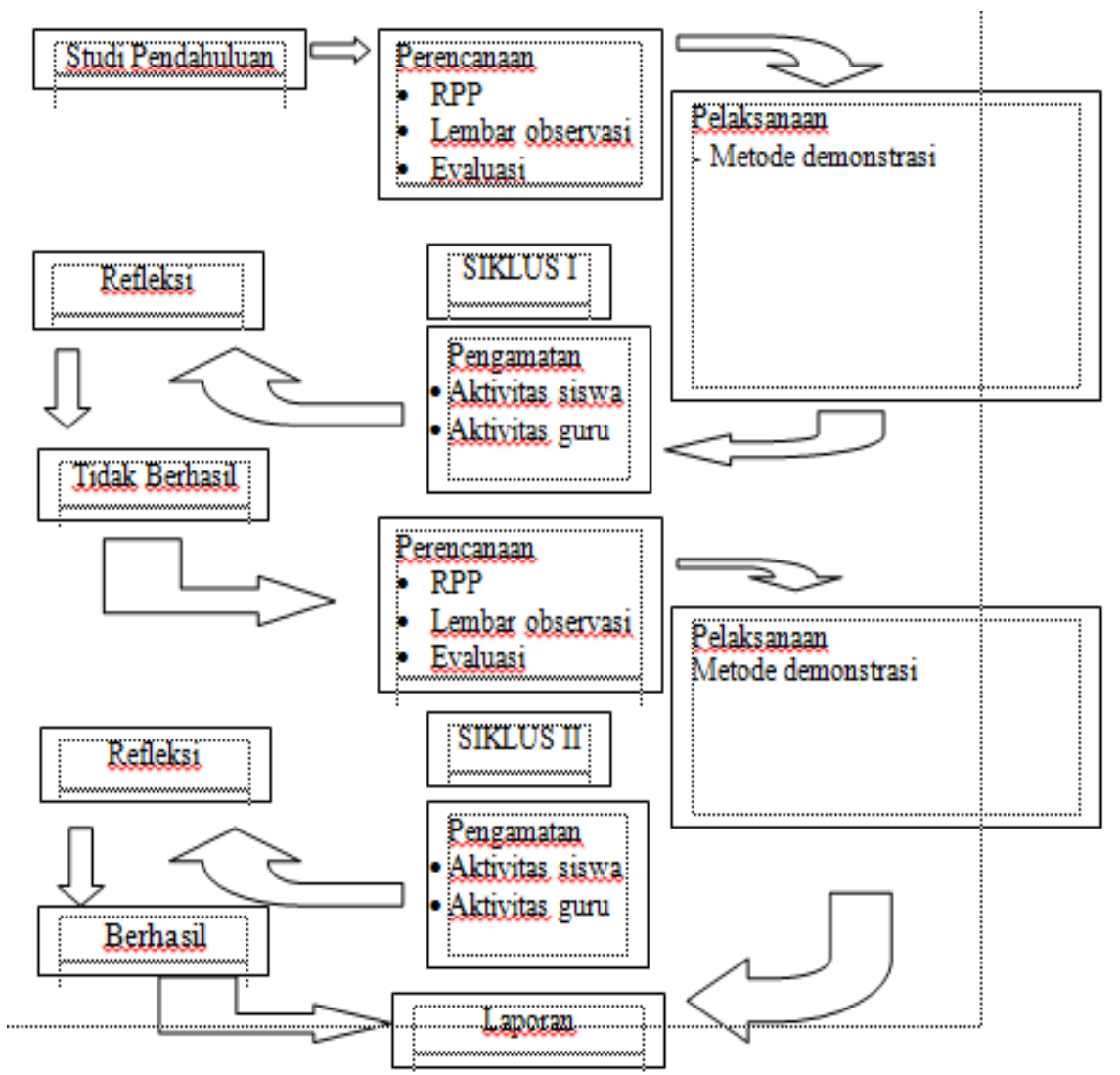

Gambar 1. Siklus Penelitian

Instrumen penelitian yang digunakan adalah lembar observasi, tes hasil belajar dan catatan lapangan, analisa data menggunakan metode kualitatif dan kuantitatif

\section{HASIL DAN PEMBAHASAN}

\section{SIKLUS 1}

\section{Pertemuan 1}

Pada pertemuan pertama ini, dilakukan pengamatan pada guru dan siswa secara sistematis. Hasil Observasi pada siklus I, pertemuan 1 di SDN 22 Koto Baru, Kecamatan Kubung dijabarkan sebagai berikut:

\section{Keterlasanaan pembelajaran}

Fokus pengamatan pada keterlaksanaan pembelajaran ini adalah keterlaksanaan langkah-langkah pembelajaran pada RPP. Keterlaksanaanya RPP ini dapat dilihat dari kegiatan guru dan kegiatan siswa selama pembelajaran dengan metode demonstrasi. Berdasarkan hasil pengamatan yang dilakukan observer diperoleh hasil sebagai berikut 
Tabel 1

Hasil Observasi Keterlaksanaan Pembelajaran

\begin{tabular}{lllll}
\hline No & \multicolumn{2}{l}{$\begin{array}{l}\text { Hasil analisis keterlakasanaan } \\
\text { kegiatan pembelajaran }\end{array}$} & Jumlah & \% \\
\hline 1 & $\begin{array}{l}\text { Jumlah } \\
\text { terlaksana }\end{array}$ & kegaiatan yang & 33 & $100 \%$ \\
\hline 2 & $\begin{array}{l}\text { Jumlah kegiatan yang tidak } \\
\text { terlaksana }\end{array}$ & 0 & $0 \%$ \\
\hline
\end{tabular}

Pada Tabel 1, Terlihat bahwa jumlah kegiatan yang terlaksana adalah 33 . Hal ini dapat diartikan bahwa semua kegiatan yang sudah terlaksana sesuai yang direncanakan

\section{Aspek pengetahuan}

Hasil evaluasi aspek pengetahuan ini tergambar pada tabel 2

Tabel 2

Hasil Evaluasi Aspek Pengetahuan Siswa

\begin{tabular}{llll}
\hline No & $\begin{array}{l}\text { Hasil analisis evaluasi } \\
\text { aspek pengetahuan }\end{array}$ & Jumlah & \% \\
\hline 1 & JumlahSiswa yang tuntas & 13 & $69 \%$ \\
\hline 2 & Jumlahsiswatidaktuntas & 7 & $35 \%$ \\
\hline
\end{tabular}

Berdasarkan hasil evaluasi aspek pengetahuan pada tabel 2, dapat disimpulkan Bahwa terjadi peningkatan hasil belajar siswa pada aspek pengetahuan. Hal ini dapat dilihat dari jumlah persentase ketuntasan siswa yang lebih tinggi dari hasil belajar sebelum tindakan dilakukan. Peningkatan persentase siswa yang tuntas adalah sebesar $25 \%$ yaitu dari $40 \%$ meningkat menjadi $65 \%$.

\section{Aspek Keterampilan}

Hasil Evaluasi aspek keterampilan ini tergambar pada tabel 3

Tabel 3

hasil Evaluasi Aspek Keterampilan Siswa

\begin{tabular}{|c|c|c|c|}
\hline No & $\begin{array}{l}\text { Hasil analisis evaluasi } \\
\text { keterampilan }\end{array}$ & Jumlah & $\%$ \\
\hline 1 & $\begin{array}{lll}\text { Jumlah } & \text { siswa } & \text { yang } \\
\text { tuntas } & & \\
\end{array}$ & 11 & $55 \%$ \\
\hline 2 & $\begin{array}{l}\text { Jumlah siswa tidak } \\
\text { tuntas }\end{array}$ & 9 & $45 \%$ \\
\hline
\end{tabular}

Pada tabel 3, terlihat bahwa siswa yang dikatakan tuntas pada evaluasi aspek keterampilan adalah sebanyak11 orang. Pada Pertemuan pertama pada siklus 1 ini, dapat disimpulkan bahwa keterampilan siswa dalam bermain bola basket sudah mulai terlihat. Untuk siswa harus mencoba bermain basket, persentase siswa yang tuntas yaitu sebesar $55 \%$ bisa dikatan bagus. 


\section{Pertemuan Kedua}

Hasil observasi dan evaluasi dari pertemuan 2 siklus 1 SDN 22 Koto Baru dapat dijabarkan sebagai berikut :

\section{Keterlakasanaan Pembelajaran}

Observasi yang dilakukan pada penelitian ini dilakukan untuk mengamati Keterlaksanaan langkah-langkah pembelajaran yang disusun telah direncanakan. Fokus observasi pada penelitian tindakan kelas ini adalah kegiatan guru dn siswa selama pembelajaran berlangsung. Hasil Observasi untuk keterlaksanaan pembelajaran dapat dijabarkan sebagai berikut :

Tabel 4

Hasil Observasi Keterlaksanaan Pembelajaran

\begin{tabular}{lllll}
\hline No & $\begin{array}{l}\text { Hasil analisis } \\
\text { keterlakasanaan } \\
\text { kegiatan pembelajaran }\end{array}$ & Jumlah & \% \\
\hline 1 & $\begin{array}{l}\text { Jumlah kegaiatan yang } \\
\text { terlaksana }\end{array}$ & 18 & $100 \%$ \\
\hline 2 & $\begin{array}{l}\text { Jumlah kegiatan yang } \\
\text { tidak terlaksana }\end{array}$ & 0 & $0 \%$ \\
\hline
\end{tabular}

Pada Tabel 4,terlihat bahwa jumlah kegiatan yang terlaksana adalah 18 kegiatan. Besarnya persentase kegiatan yang terlaksana, menggambarkan bahwa semua langkah-langkah kegiatan pembelajaran yang disusun dalam RPP sudah terlaksana.

\section{Apek Pengetahuan}

Hasil evaluasi aspek pengetahuan ini tergambar pada tabel 5.

Tabel 5

Hasil Evaluasi Aspek Pengetahuan Siswa

\begin{tabular}{|l|l|l|l|}
\hline No & Hasil analisis evaluasi aspek pengetahuan & Jumlah & \% \\
\hline 1 & Jumlah siswa yang tuntas & 15 & $75 \%$ \\
\hline 2 & Jumlah siswa tidak tuntas & 5 & $25 \%$ \\
\hline
\end{tabular}

Pada Tabel 5, Terlihat bahwa siswa yang tuntas sebesar $75 \%$ dan siswa yang tidak tuntas sebesar $25 \%$. Dari besarnya persentase ketuntasan siswa dapat disimpulkan bahwa jumlah siswa yang tuntas pada pertemuan kedua ini meningkat dibandingkan sebelumnya. 


\section{Aspek Keterampilan}

Hasil evaluasi aspek keterampilan ini tergambar pada tabel 6

Tabel 6

Hasil Evaluasi Aspek Keterampilan Siswa

\begin{tabular}{llll}
\hline No & $\begin{array}{l}\text { Hasil analisis evaluasi } \\
\text { keterampilan }\end{array}$ & Jumlah & $\%$ \\
\hline 1 & Jumlah siswa yang tuntas & 14 & $70 \%$ \\
\hline 2 & Jumlah siswa tidak tuntas & 6 & $30 \%$ \\
\hline
\end{tabular}

Pada pertemuan kedua ini, persentase ketuntasan siswa pada aspek ketermapilan sudah meningkat menjadi $70 \%$

\section{Refleksi (Reflection)}

Refleksi dilakukan untuk menemukan kendala yang terjadi saat pembelajaran. Refleksi dilakukan bersama teman sejawat, dengan mendiskusikan hal-hal yang masih belum maksimal terlaksana, sehingga dapat diperbaiki pada pertemuan selanjutnya.Berdasarkan hasil diskusi dengan teman sejawat, diperoleh kesepakatan bahwa pada pertemuan pertama masih terdapat beberapa kendala, yaitu:

1. Masih ada siswa yang tidak memperhatikan guru saat menyampaikan informasi tujuan pembelajaran.

2. Diskusi yang dilakukan belum lancar, terutama ketika siswa mempresentasikan hasil diskusi

3. Kegiatan tanya jawab antara siswa yang satu dengan yang lainnya belum berjalan dengan baik

4. Guru masih kesulitan untuk meminta siswa mendemonstrsikan gerakan didepan kelas

5. Masih ada siswa yang tidak memperhatikn guru saat mendemonstrasikan gerakan, terutama siswa perempuan

Selain ditemukan kendala, juga ditemukan beberapa dampak positif dari pembelajaran yang dilakukan, yaitu:

1. Pembelajaran yang dilakukan lebih bermakna karena pengetahuan yang diperoleh ditemukan sendiri oleh siswa

2. Kegiatan pembelajaran yang dilakukan meningkatkan aktivitas siswa salah satunya melatih kemampuan berbicara siswa

3. Pemblajaran dengan metode demonstrasi memudahkan siswa dalam memahami materi dan memahami gerakan

\section{SIKLUS 2}

\section{Pertemuan 1}

Pada pertemuan pertama ini, dilakukan pengamatan pada guru dan siswa secara sistematis. Hasil Observasi pada siklus 2, pertemuan 1 di SDN 22 Koto Baru, Kecamatan Kubung dijabarkan sebagai berikut:

\section{Keterlasanaan Pembelajaran}

Fokus pengamatan pada keterlaksanaan pembelajaran ini adalah keterlaksanaan langkah-langkah pembelajaran pada RPP. Keterlaksanaanya RPP 
ini dapat dilihat dari kegiatan guru dan kegiatan siswa selama pembelajaran dengan metode demonstrasi. Berdasarkan hasil pengamatan yang dilakukan observer diperoleh hasil sebagai berikut :

Tabel 7

Hasil Observasi

\begin{tabular}{|l|l|l|l|}
\hline No & $\begin{array}{l}\text { Hasil analisis keterlakasanaan } \\
\text { kegiatan pembelajaran }\end{array}$ & Jumlah & $\%$ \\
\hline 1 & Jumlah kegiatan yang terlaksana & 23 & $100 \%$ \\
\hline 2 & $\begin{array}{l}\text { Jumlah kegiatan yang tidak } \\
\text { terlaksana }\end{array}$ & 0 & $0 \%$ \\
\hline
\end{tabular}

Terlihat bahwa jumlah kegiatan yang terlaksana adalah 23 kegiatan. Hal ini dapat diartikan bahwa semua kegiatan yang sudah terlaksana sesuai yang direncanakan.

\section{Aspek pengetahuan}

Hasil evaluasi aspek pengetahuan ini tergambar pada tabel 8

Tabel 8

Hasil Evaluasi Aspek Pengetahuan Siswa

\begin{tabular}{|l|l|l|l|}
\hline No & $\begin{array}{l}\text { Hasil analisis evaluasi aspek } \\
\text { pengetahuan }\end{array}$ & Jumlah & $\%$ \\
\hline 1 & Jumlah Siswa yang tuntas & 16 & $80 \%$ \\
\hline 2 & Jumlah siswa tidak tuntas & 4 & $20 \%$ \\
\hline
\end{tabular}

Berdasarkan hasil evaluasi aspek pengetahuan pada tabel 8, dapat disimpulkan Bahwa terjadi peningkatan hasil belajar siswa pada aspek pengetahuan. Hal ini dapat dilihat dari jumlah persentase ketuntasan siswa yang lebih tinggi dari hasil belajar sebelum tindakan dilakukan. Peningkatan persentase siswa yang tuntas adalah sebesar $10 \%$ yaitu dari $70 \%$ meningkat menjadi $80 \%$

\section{Aspek Keterampilan}

Hasil Evaluasi aspek keterampilan ini tergambar pada tabel 9

Tabel 9

Hasil Evaluasi Aspek Keterampilan Siswa

\begin{tabular}{llll}
\hline No & Hasil analisis evaluasi keterampilan & Jumlah & $\%$ \\
\hline 1 & Jumlah siswa yang tuntas & 16 & $80 \%$ \\
\hline 2 & Jumlah siswa tidak tuntas & 4 & $20 \%$ \\
\hline
\end{tabular}

Pada tabel 9, terlihat bahwa siswa yang dikatakan tuntas pada evaluasi aspek keterampilan adalah sebanyak 16 orang. Jadi, dapat disimpulkan Pada Pertemuan pertama pada siklus 2 ini, juga terjadi peningkatan hasil belajar siswa pada aspek keterampilan menjadi $80 \%$ 


\section{Pertemuan Kedua}

Hasil observasi dan evaluasi dari pertemuan 2 siklus 2 SDN 22 Koto Baru dapat dijabarkan sebagai berikut :

\section{Keterlakasanaan Pembelajaran}

Observasi yang dilakukan pada penelitian ini dilakukan untuk mengamati Keterlaksanaan langkah-langkah pembelajaran yang disusun telah direncanakan. Fokus observasi pada penelitian tindakan kelas ini adalah kegiatan guru dan siswa selama pembelajaran berlangsung. Hasil Observasi untuk keterlaksanaan pembelajaran dapat dijabarkan sebagai berikut

Tabel 10.

Hasil Observasi Keterlaksanaan Pembelajaran

\begin{tabular}{llll}
\hline No & $\begin{array}{l}\text { Hasil analisis keterlakasanaan } \\
\text { kegiatan pembelajaran }\end{array}$ & Jumlah & $\%$ \\
\hline 1 & Jumlah kegaiatan yang terlaksana & 20 & $100 \%$ \\
\hline 2 & $\begin{array}{l}\text { Jumlah kegiatan yang tidak } \\
\text { terlaksana }\end{array}$ & 0 & $0 \%$ \\
\hline
\end{tabular}

Pada Tabel 10 ,terlihat bahwa jumlah kegiatan yang terlaksana adalah 20 kegiatan. Besarnya persentase kegiatan yang terlaksana, menggambarkan bahwa semua langkah-langkah kegiatan pembelajaran yang disusun dalam RPP sudah terlaksana.

\section{Aspek Pengetahuan}

Hasil evaluasi aspek pengetahuan ini tergambar pada tabel 11

Tabel 11

Hasil Evaluasi Aspek Pengetahuan Siswa

\begin{tabular}{|l|l|l|l|}
\hline No & $\begin{array}{l}\text { Hasil analisis evaluasi aspek } \\
\text { pengetahuan }\end{array}$ & Jumlah & $\%$ \\
\hline 1 & JumlahSiswa yang tuntas & 18 & $90 \%$ \\
\hline 2 & Jumlahsiswatidaktuntas & 2 & $10 \%$ \\
\hline
\end{tabular}

Pada Tabel 11, Terlihat bahwa siswa yang tuntas sebesar $90 \%$ dan siswa yang tidak tuntas sebesar $10 \%$. Dari besarnya persentase ketuntasan siswa dapat disimpulkan bahwa jumlah siswa yang tuntas pada pertemuan kedua ini meningkat dibandingkan sebelumnya.

\section{Aspek Keterampilan}

Hasil evaluasi aspek keterampilan ini tergambar pada tabel 12

Tabel 12

Hasil Evaluasi Aspek Keterampilan Siswa

\begin{tabular}{llll}
\hline No & Hasil analisis evaluasi keterampilan & Jumlah & $\mathbf{\%}$ \\
\hline 1 & Jumlah siswa yang tuntas & 17 & $85 \%$ \\
\hline 2 & Jumlah siswa tidak tuntas & 3 & $2 \%$ \\
\hline
\end{tabular}


Pada pertemuan kedua ini, persentase ketuntasan siswa pada aspek ketermapilan sudah meningkat menjadi 85\%. Hal ini berarti telah terjadi peningkatan hasil belajar pada aspek keterampilan materi permainan bola basket.

\section{Refeksi (Reflection)}

Refleksi dilakukan umtuk menemukan kendala yang terjadi saat pembelajaran. Refleksi dilakukan bersama dengan teman sejawat, dengan mendiskusikan hal-hal yang masih belum maksimal terlaksana sehingga dapat diperbaiki pada pertemuan selanjutnya. Berdasarkan hasil-hasil diskusi dengan teman sejawat, diperoleh kesepakatan bahwa pada pertemuan pertama masih terdapat beberapa kendala yaitu:

1. Masih ada siswa yang tidak memperhatikan guru saat menyampaikan informasi dan tujuan pembelajaran

2. Diskusi yang dilakukan sudah lancar, akan tetapi ketika siswa menyampaikan hasil diskusi masih memerlukan bimbingan guru

3. Kegiatan tanya jawab antara siswa yang satu dengan yang lainnya sudah mulai berjalan dengan baik, meskipun siswa masih membutuhkan arahan guru dalam menjawab pertanyaan

Selain ditemukan kendala, juga ditemukan beberapa dampk positif dari pembelajaran yang dilakukan yaitu :

1. Pembelajaran yang dilakukan lebih bermakna karena pengetahuannya yang diperoleh ditemukan sendiri oleh siswa

2. Kegiatan pembelajaran yang dilakukan meningkatkan aktivitas siswa, salah satunya melatih kemampuan berbicara siswa

3. Pembelajaran dengan metode demonstrasi memudahkan siswa dalam memahami materi dan memahami gerakan

\section{SIMPULAN}

Pembelajaran dengan metode demonstrasi, tidak hanya dapat meningkatkan hasil belajar siswa pada aspek pengetahuan, akan tetapi juga dapat meningkatkan keterampilan siswa karena siswa dalam pembelajaran diminta secara langsung mendemonstrasikan gerakan-gerakan dalam permainan bola basket.

\section{DAFTAR PUSTAKA}

Dahar, R., W.(1989).Teori-teori Belajar.Bandung: Erlangga

Djmarah, S., B. (2008). Psikologi.Belajar .Jakarta :Rineka Cipta

Suprihatiningsih, J. (2013). Strategi Pembelajaran Teori dan aplikasi Yogyakarta: Ar-ruzz Media

Suryabrata, S. (1983). Proses Belajar mengajar di perguruan tinggi. Yogyakarta :Andi Offset

Permendiknas Nomor. 22. Tahun 2006 tentang Standar Isi untuk Satuan Pendidikan Dasar dan Menengah

Sodikun. (1992). Permaianan Bola Basket. Jakarta: Pustaka Setia

Winasanjaya. (2010). Langkah Mudah Penelitian Tindakan Kelas sebagai Pengembangan Profesi guru. Jakarta : Rajawali. Pers 